\title{
論文投稿に見るSOFT の歩み
}

\author{
高間 康史（首都大学東京システムデザイン学部）
}

\section{1. はじめに}

本稿では, 学会誌に投稿・掲載された論文について 定量的なデータを示し，学会の歩みを論文投稿の観点 から振り返る。対象とする期間は，2003年 1 月から 2008年12月に投稿あるいは揭載された論文とする. これは, 2003年 1 月に学会名が「日本知能情報ファ ジィ学会」に変更となり, それに伴い会誌名が「知能と 情報」となってからの期間に該当する.

学会の組織上は，2002年に会誌編集委員会が関西 から関東に移るという大きな変更があり，2002年 3 月号からは関東の編集委員会が担当している。従っ て, 10周年記念号以降の学会の歩みを振り返る上で, この期間を対象とするのがふさわしいと考えた。筆者 自身, 関東の会誌編集準備委員会発足時から編集委員 として参加し，2003年 6 月から2009年 5 月まで論文 委員長を務めたことも，この期間を対象とした理由の 一つである。

本稿では,「知能と情報」に名称変更してからの論文 投稿の動向について，2 節にて客観的データを引用し つつ述べる。 また, 近年最大の変革である, 論文投稿 審査システムの電子化など, 論文審査プロセスについ ては 3 節にまとめる.

\section{2. データで振り返る論文投稿の動向}

「日本ファジィ学会」から「日本知能情報ファジィ学 会」への学会名称の変更は, 会誌が対象とすべき学術 分野や読者層の変化を伴うものである. 従って, 関西 の会誌編集委員会から引き継いだ関東の会誌編集委員 会では, 会誌のクオリティを保ちつつ, 学会および会 誌名称の変更に伴う変化を取り入れ, さらなる誌面の 充実, 論文投稿数の増加などを目指してきた。これま でに様々な企画を検討・実施してきたが，論文投稿に 関連する主な成果としては以下が挙げられる。

（1）特集論文の積極的な企画

（2）対象分野を広く知能情報分野へ拡大

(3) 実践研究論文の創設

（4）J-STAGEを利用した論文の電子的公開
（5）論文投稿審査システムの電子化

以下では各成果について, 関連するデータを示しな がら説明していく（5)については 3 節で説明する.

なお，本稿の掲載号に掲載される，片上氏による提 言論文[1]にも，本稿とは異なる観点，データによる 論文投稿の分析結果が示されているので, あわせて参 照されたい.

\section{1 特集論文の積極的な企画}

特集論文とは，ある特定の分野や技術について，そ れに関連する論文の投稿を広く呼びかけ，採録された 論文をある特定の号にまとめて掲載するものである. 特集分野に打いて高い専門性を有し, 活発に活躍され ている研究者にゲストエディタを㹉いし，投稿論文 の判定などをお願いしているが, 查読手順や判定の基 準は一般投稿と同様である。

特集号を積極的に企画した理由は，学会に関連があ るがこれまであまり取り上げられて来なかった話題を 積極的に取り込んでいくためである。「あいまいさ」を ファジィ理論にとらわれず広く考えた場合, 関連分野 は数多く存在する。また, Webなど新しい応用領域 や, 学際的研究分野の増加なども, 学会に関連する話 題・分野の増加につながっている。これらの関連分野 について特集を企画し，広く論文投稿を募ることによ り，以下の二つの効果が期待できる.

（1）学会員に関連分野についての情報を提供

(2) 非会員の関心をひきつける

（1）は，会誌が担うべき役割の一つであるが，この 点は解説特集でも同様の効果があるといえる。一方, (2) は特集論文でこそより効果が大きいと言える。本 学会は以前より非会員の投稿を認めており, 別刷り費 は学会員よりも高くなるが, 著者が全員非会員であっ ても投稿可能である. 従って, 学会HPや各種メーリ ングリストなどで広く広報活動を行う事により, 関連 分野の研究者に, 本学会の存在をアピールし, 論文投 稿先の一つとして認知してもらう効果も期待できる. 
以上の考えに基づき, ファジィ, ソフトコンピュー ティングに関わらず，その応用分野や周辺分野も積極 的に取り入れ。論文特集を企画してきた。表 1 に， 2003 2008年の間に企画された特集論文についてま とめる. また，一般投稿と特集論文の投稿数の変化に ついて図 1 に，論文投稿数に占める特集論文の割合の 変化について図 2 にそれぞれ示す。なお，図 $1 ， 2$ に 示すのは，その年に掲載された論文数ではなく，投稿 された論文数であることに注意されたい．

表 1 に示した中には,「ソフトサイエンス研究部会」 (2004年2月号)や「脑と知覚」(2006年6月号)，「曖昧な 気持ちに挑む」(2008年12月号)など本学会の研究部会 を中心として企画された論文特集もある。本学会で活

表 1 特集論文企画の概要

\begin{tabular}{|c|c|}
\hline 月 & 特集論文企画名 \\
\hline \multicolumn{2}{|r|}{2003} \\
\hline 2 & リスク工学 \\
\hline 6 & チャンス発見とソフトコンピューティング \\
\hline 10 & ソフトコンピューティングとインターネット \\
\hline \multicolumn{2}{|r|}{2004} \\
\hline 2 & ソフトサイエンス研究部会 \\
\hline \multicolumn{2}{|r|}{2005} \\
\hline 2 & 理解技術におけるソフトコンピューティング \\
\hline 4 & エンターテインメントコンピューティング \\
\hline 6 & IDEA : 適応のためのインタラクション設計 \\
\hline 10 & 高等教育と情報 \\
\hline \multicolumn{2}{|r|}{2006} \\
\hline 4 & Web インテリジェンスとインタラクション \\
\hline 6 & 脳と知覚 \\
\hline 8 & 人間要素を取り込む計算知能 \\
\hline 10 & テキストの可視化と要約 \\
\hline 12 & $\begin{array}{l}\text { 運輸分野におけるソフトコンピューティングの応 } \\
\text { 用 }\end{array}$ \\
\hline \multicolumn{2}{|r|}{2007} \\
\hline 2 & 曖昧な気持ちに挑む \\
\hline 6 & セキュリティとトラスト \\
\hline 10 & 人工知能的方法論を用いた知的画像処理 \\
\hline \multicolumn{2}{|r|}{2008} \\
\hline 2 & 医用システム \\
\hline 4 & 日常生活行動コンピューティング \\
\hline 8 & ソーシャルインテリジェンス \\
\hline 10 & 言語, テキストの知能情報処理 \\
\hline 12 & 最適化問題へのアプローチ \\
\hline
\end{tabular}

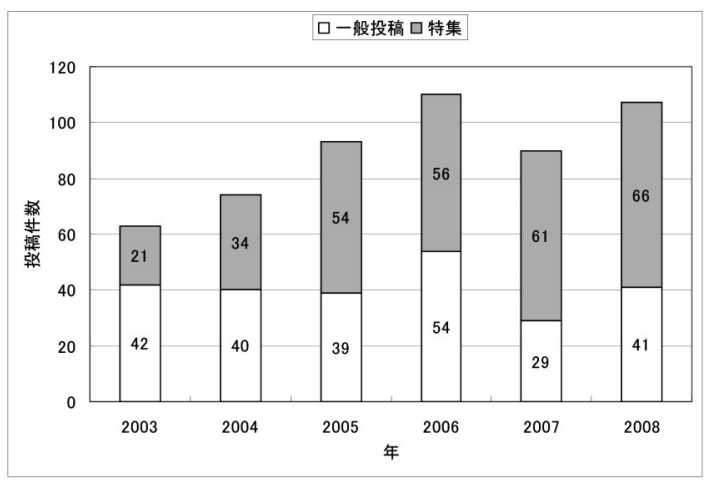

図 1 一般投稿と特集論文の投稿数の変化

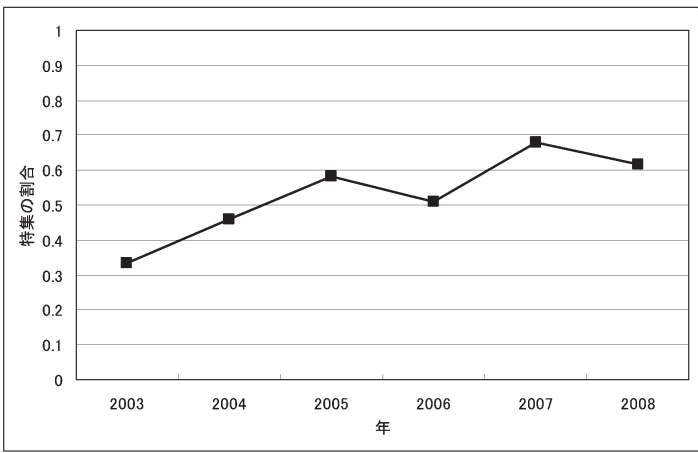

図 2 論文投稿に占める特集論文の割合の変化

発に活動されている研究部会との連携は，会誌編集， 研究部会共に好ましいものであり, 今後も積極的に取 り組んでいく予定である.

図 1，2より，論文投稿総数に占める特集論文の割 合は増加傾向にあり，2005年以降は半数以上が特集 論文であることがわかる。この理由として，特集論文 は掲載号が決まっているため, 博士後期課程学生など にとってはスケジュールが立てやすいことなどもある と考える.

特集号の中には非常に大規模となるものもあった。 掲載論文数が 10 本以上となった特集を，掲載論文数の 順に表 2 にまとめる.

な打, 前述の効果 $(2) に$ 挙げた, 非会員の関心をひ きつける効果に関して, 会員/非会員による一般投稿 数の推移を図 3 に示す。ここで, 著者の中に一人でも 会員が含まれる場合は会員による投稿としている。 2003年には, 非会員による一般投稿はなかったが， その後は増加傾向にあることがわかる，中には，特集 論文に初めて投稿・採録された後，一般投稿するよう になった投稿者も複数存在している。これは，特集号 を契機として, 本会誌が論文投稿先の一つとして認知 
された事を意味しており，非会員の関心を引き付ける 効果があったと言える。また，掲載された論文におけ る会員／非会員数については, 文献[1]にデータが示 されているので参照されたい。

投稿者層の変化は, 掲載される論文の内容や質に影 響を与えることが考えられる。内容の変化に関しては 次節で述べるが，ここでは質について，採択率の観点 から考察する。一般投稿された論文の採択率につい て，その推移を図 4 に示す。2003２008年を通して

表 2 掲載論文数による特集ランキング

\begin{tabular}{|c|l|c|c|}
\hline 順位 & \multicolumn{1}{|c|}{ 特集名 } & 年月 & 本数 \\
\hline 1 & $\begin{array}{l}\text { Web インテリジェンスとイン } \\
\text { タラクション }\end{array}$ & 2006.4 & 16 \\
\hline 2 & $\begin{array}{l}\text { 人工知能的方法論を用いた知 } \\
\text { 的画像処理 }\end{array}$ & 2007.10 & 12 \\
\hline 2 & 医用システム & 2008.2 & 12 \\
\hline 2 & ソーシャルインテリジェンス & 2008.8 & 12 \\
\hline 5 & $\begin{array}{l}\text { エンターテインメントコンピ } \\
\text { ユーティング }\end{array}$ & 2005.4 & 10 \\
\hline
\end{tabular}

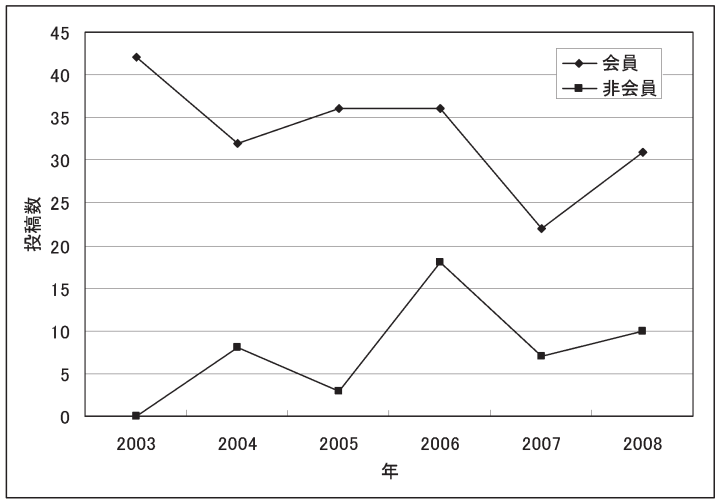

図 3 会員/非会員の一般投稿数の推移

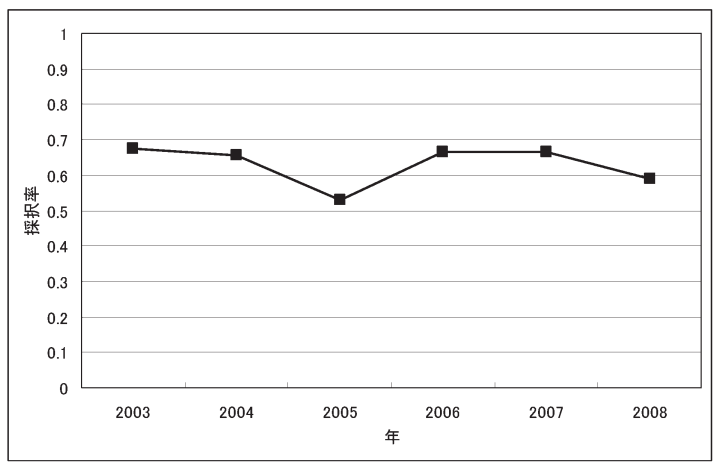

図 4 一般投稿の採択率の変化
の採択率は63.1\%である。図を見ると，年によって多 少の変動はあるものの, 大体 $2 / 3$ 程度の採択率となっ ており, 論文の質については大きく変動していないと 考えている.

\section{2 対象分野の拡大}

前節とも関連するが，学会及び会誌名称の変更を契 機として, 会誌で取り上げる対象分野の拡大に努めて きた。それは，特集論文の企画だけにとどまらず，特 集および単発の解説や, 用語解説などの記事において も同様の意図を持って進めてきた。中には，「チャン ス発見」の様に, 最新のキーワードとして用語解説で 取り上げた後, 論文特集を企画したものもある.

対象分野の拡大・変遷については, 文献 [1]で詳細 に分析されているが，本稿では特集を含む解説および 論文の「キーワード闌」に記載されたキーワードの遷移 について表 3 に示す. 表 3 では, 創刊時から2007年 までを 5 年毎(創刊時のみ 4 年)の 4 区間に区切り，そ れぞれに打いて出現頻度 (論文・記事数)の高い上位 10 キーワードを示している。ここで，1989-1992年と 2003-2007年は, 10位のキーワードが多数存在するた

表 3 頻出キーワードの遷移

\begin{tabular}{|c|c|}
\hline 区間 & 頻出キーワード \\
\hline $\begin{array}{c}1989 \\
-1992\end{array}$ & $\begin{array}{l}\text { ファジィ制御(32)，ファジィ推論(25)，ファ } \\
\text { ジィ集合論(18), ファジィ理論(13), ニュー } \\
\text { ラルネットワーク(11), メンバシップ関数 } \\
\text { (11), エキスパートシステム(8), ファジィ数 } \\
\text { (7), 意思決定 }(7)\end{array}$ \\
\hline $\begin{array}{c}1993 \\
-1997\end{array}$ & $\begin{array}{l}\text { ファジィ推論(60), ファジィ制御(30), 遺伝 } \\
\text { 的アルゴリズム(27), ファジィ論理(19), 意 } \\
\text { 思決定(18), ニューラルネットワーク(14), } \\
\text { ファジィ目標(13), ファジィモデリング } \\
\text { (13), ファジィニューラルネットワーク(9), } \\
\text { ファジィ If-Then ルール(8) }\end{array}$ \\
\hline-2002 & $\begin{array}{l}\text { 遺伝的アルゴリズム }(28), \text { ファジィ目標 } \\
\text { (16), ファジィクラスタリング(15), ファジ } \\
\text { イ推論(14), パターン認識(10), 意思決定(8), } \\
\text { ファジィ制御(8), シミュレーション(8), 推 } \\
\text { 論(8), 推論モデル(8) }\end{array}$ \\
\hline 2003 & $\begin{array}{l}\text { ファジィ推論(14), 遺伝的アルゴリズム } \\
(13), \text { ニューラルネットワーク }(7) \text {, クラス } \\
\text { タリング(6), 自己組織化マップ(6), ファジ } \\
\text { イ測度(5), Webマイニング(4), テキストマ } \\
\text { イニング(4), シラバス(4) }\end{array}$ \\
\hline
\end{tabular}


め 9 位までを示している。これより，ファジィ，ソフ トコンピューティングに関連するキーワードがどの区 間でも上位に出現しているが，2003年以降ではWeb マイニングやテキストマイニングなど，特集の影響を 受けたキーワードが上位に来ていることがわかる。な お，各区間におけるキーワードの延べ出現回数は以下 の通りである。

$\cdot 1989-1992: 731$

$\cdot 1993-1997: 1456$

-1998-2002: 928

$\cdot 2003-2007: 854$

1993-1997年を除く 3 区間で，キーワードの延べ出 現回数に大きな違いはないが，表 3 を見ると，20032007年の頻出キーワードの出現回数は他の区間より も小さくなっている。このことは, 多様なキーワード が利用されていることを意味して打り，会誌が扱う分 野の多様化を表していると言える。

\section{3 実践研究論文}

本学会には, 原著論文, ショートノート, 総説論 文, 実践研究論文の 4 種類の論文区別が存在する。こ のうち, 実践研究論文は,「知能と情報」になってから 新たに創設されたものである。

実践研究論文は, 会誌編集委員会が関東に移った当 初から議論がされており，その目的は産業界からの論 文投稿を促進する事であった。ファジィ家電やプラン 卜制御など，日本ではファジィの産業応用が活発に行 われて打り，これが日本発のファジィブームを引き起 こした要因の一つと言える。しかし，産業界の人が論 文を投稿しようとすると，学術的な新規性の点で必ず しも評価されなかったり, 評価結果の詳細が企業秘密 の観点から公開できなかったりといった問題が指摘さ れていた。実践研究論文は, その様な問題を解消し, 産業界からも投稿しやすい種別として検討されてい た。

実践研究論文の概要は, 以下の通りである ${ }^{1}$.

実践研究論文はソフトウェア，ハードウェアを問わ ず，企業・大学・官公庁研究機関等において研究・開 発された技術あるいは知見に関する成果をまとめた研 究論文です，既存のシステム・装置などの利用方法・ 性能比較などの成果をまとめたケーススタディ論文も 含みます。対象とする技術・システム等の仕組み、あ るいは技術・知見の評価が明確に記述されていること

1 http://www.j-soft.org/journal/kitei/toukou.html
が必要です。

上記概要を読むと, ケーススタディといった言葉が 使われているせいか，他学会ではショートノートに相 当する，技術報告と勘違いして投稿されるようなケー スもあった。しかし，実践研究論文として掲載される 論文が増えてくるに伴い, 趣旨が正しく理解されるよ うになったと感じている。

また，査読においても，実践研究論文の主旨を十分 理解した上で査読してもらう必要がある。原著論文と 同様の依頼形式では，例え上記概要を伝えたとして も，査読を行う事は困難と考えた。そこで，当初は該 当分野についての専門性を持つ研究者と, 編集委員 で，論文毎にワーキンググループを構成し，査読を 行っていたが，他の種別と査読プロセスを統一すべき であること，打よび査読にかかる負担を軽減するため に，現在では投稿時に以下の 2 点についての説明を提 出することになっている。

1. どの様な観点から実践研究論文に該当するか

2.どの様な観点から技術・知見の評価などを行って いるか

査読依頼時には，上記についての説明を查読者に伝 え, 査読の際に考慮してもらっている.2003-2008年の 間に掲載された論文について，論文種別の内訳を図 5 に示す。原著論文が大部分であるが, 実践研究論文の 投稿も全投稿の $3 \%$ あり, 論文種別として定着してき ていることがわかる.

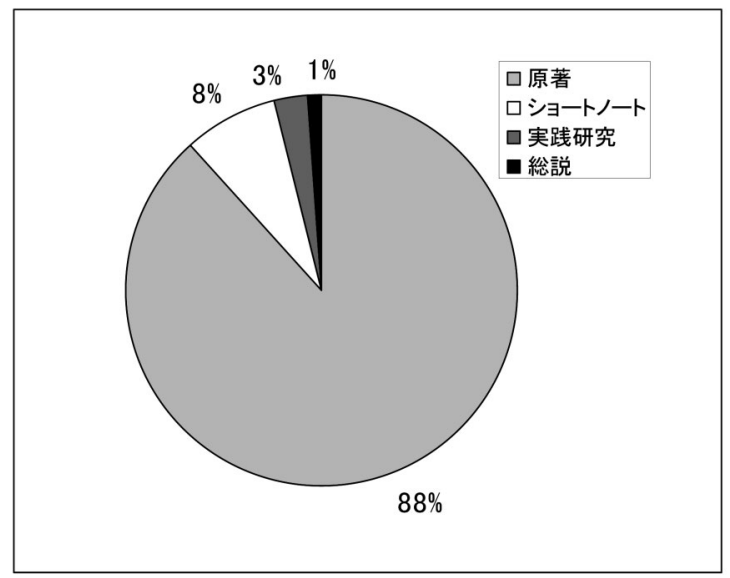

図 5 掲載論文に打ける論文種別の内訳(2003-2008) 


\subsection{J-STAGEを利用した論文の電子公開}

J-STAGEとは, 独立行政法人科学技術振興機構 (JST) が構築した，学協会による情報発信を支援する システムであり, 多数の学会誌・論文誌などの電子公 開を行っている $[2]$. 公開機能だけでなく, 論文審査 など電子ジャーナル出版に必要な機能を包括的に備え ている。本会誌は，2007年 4 月より，Vol.18 (2006) 以降の論文を順次公開している。本学会としては, 会 誌の他にFSSPSCIS\&ISISの予稿集も公開している.

会誌の電子公開に関しては, J-STAGEでの公開以 前にも行っていた。学会としては, 文献データベース 委員会により運営されている「ファジィ文献データ ベース」゚にて, 国内のファジィ理論関連の文献を広く 収集し，その書誌情報を公開している。また，国立情 報学研究所が運営しているCiNii ${ }^{3}$ では, 創刊号からの 会誌記事・論文が閲覧可能であり, 公開から 5 年以上 経過したものは無料公開されている。ただし，CiNii とJ-STAGE両方の利用は今後できなくなる予定であ る.

CiNiiなどで，すでに電子公開を行っている状況で, さらにJ-STAGEでの電子公開を決めた理由は, JSTAGEの投稿審查システムを利用するためであっ た。投稿審査システムを利用するためには，このシス テムを利用して刊行されたジャーナルをJ-STAGE上 で公開することが必須であったためである。公開にあ たっては, CiNiiとの関係や, 課金の有無などについ て, 理事会および会誌編集委員会で慎重な議論がなさ れたが, 多数の人に読んでもらえるという「投稿者に とってのメリット」扰よ゙゙学会のプレゼンスの観点か らのメリット」と，「会員と非会員に対するサービスの 差別化」のバランスを考慮した結果, 論文のみを無料 公開することに決定した。

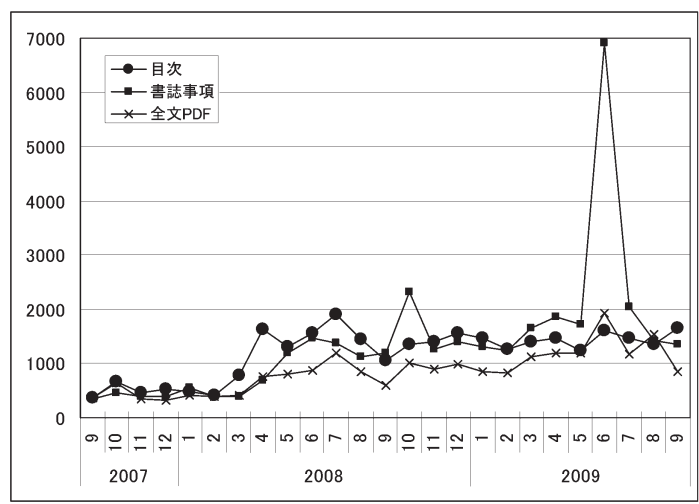

図 6 J-STAGEアクセス数の推移

2 http://www.wadatsumi.ipc.tcu.ac.jp/ fuzdb/

3 http://ci.nii.ac.jp/
図 6 に, 「知能と情報」の目次, 書誌事項, 全文PDF に対するアクセス数の経緯をまとめる。2008年 5 月 頃に目次や書誌情報へのアクセスが1000回を越えて 以降, 一定数のアクセスを集めていることがわかる.

\section{3 . 論文投稿審㚗システムの電子化}

会誌に打ける, 近年の大きな出来事は, 電子投稿へ の移行である。論文投稿審査システムの電子化は, 総 会などでも要望が出されるなど, 以前より検討されて きていたが，導入に踏み切れずにいた，論文受付が事 務局ではなく論文委員長が行うシステムになっている こと, 拈よび学会でWebサーバを持っていないこと， などが主な理由であり, 開発コストの問題だけでな く, システム保守・運用も含め検討すべき課題が多く 残されていた。その様な時に, J-STAGEによる論文 投稿審查システムの話があり, 以下のメリットがある ことから採用に踏み切った。

・イージーオーダーであること：いくつかの論文投稿 プロセスのひな形が用意されて打り，学会に一番近い ものを選んでカスタマイズできること

・サーバの運用はJ-STAGEが行う事

・公開するデータ作成費用を除き，無料で利用できる こと

2006年より, 当時論文委員長であった筆者をリー ダーとして, 電子ジャーナル化ワーキンググループを 立ち上げ, 論文の電子公開の検討・実施, 続いて論文 投稿審査システムのカスタマイズなどを行い, 2008 年 9 月 1 日より運用を開始した. 現時点まで, 特に大 きな障害などは発生しておらず，順調に運用されてい る. 完全なオーダーメイドではないため, 運用でカ バーしなくてはいけない面もあるが, 筆者の知る限 り, 他学会の論文投稿審査システムと比較しても同等 かそれ以上の使い勝手ではないかと感じている。なに より, J-STAGE以外では, これだけ短時間でシステ 么開発・運用にこぎ着けることはできなかったと考え る。な打, 本学会がJ-STAGEの論文投稿審査システ ムの採用を決定した頃，すでに利用している，あるい は検討中の学協会は少なかったが, 現在では利用を希 望する学会が多数あり, 待ち行列に並んでいるとのこ とである。

電子投稿となったことにより，投稿原稿の印刷・郵 送が不要になるといったメリットがあるため, より投 稿しやすくなったと言える. また, 論文受付や查読に おいて発生する事務作業にかかる時間の短縮も期待で きる.すなわち, 郵送で論文を受け付けていた時代に 
は，投稿論文を論文委員長の所属機関に送付する必要 があり，查読を依頼する際にも論文を郵送する必要が あった。このため, 郵送に時間がかかるだけでなく, 論文委員長や査読者が出張中だったり，所属機関が夏 季休業期間中で事務が休止していたりすると，大幅な 時間ロスが発生していた。論文投稿システムが電子化 されたことにより, 查読者が出張中でも対応可能に なったことは大きなメリットと言える。

2003〜2008年の間に掲載された論文に関して，投 稿受付から採録決定までにかかった日数のヒストグラ ムを図 7 に示す。ショートノートを除く全論文につい て，特集論文と一般投稿に分けて計算している。電子 投稿の受け付け開始は 2008 年 9 月からであるため, このデータの殆どは郵送受付のものである．特集論文 は平均 108 日，一般論文は平均 269 日かかっている が，図 7 を見るとわかると打り，論文毎にばらつきが 多い，標準的なケースとして，特集号では $3 ， 4$ ケ 月，一般投稿では $9 ， 10$ ケ月かかる場合が多いことが わかる。なお，図には不採録となった論文は含まれて いない，採録となる論文は再査読となるケースが多い のに対し，不採録論文は 1 回目の査読で判定が出る場 合が多い，従って，例外はあるものの，不採録論文の 方が審査にかかる日数は短い傾向にあるため, 投稿論 文全体で見た時の審査にかかる日数は，本稿に示した よりも短くなる。

論文審查プロセスにおいて，時間がかかる要因は主 に以下の 6 点である.

（1）事務作業(投稿受付，査読依頼，報告受付，結果 通知など）

(2) 担当委員割当

(3) 査読者割当

(4) 査読

(5) 再査読

（6）判定割れ

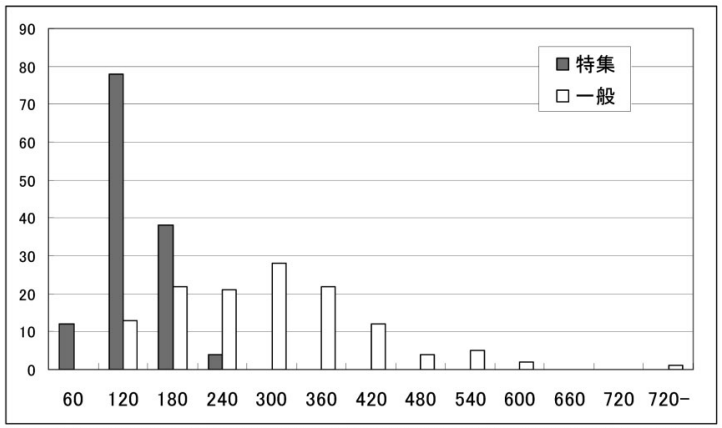

図 7 論文審査にかかる日数の分布
このうち，(1)については前述の通り, 電子投稿に よる時間短縮が期待できるが，(2)〜 (6) は投稿システ ムとは無関係であるため, 電子投稿への切り替えによ り短縮化されるものではない，(2)に関して，本学会 では担当編集委員制を採用しており，投稿論文毎に担 当する編集委員を決め, 査読者の依頼, 審査報告など を行う。担当は，専門性と負荷バランスを考慮して決 定するため, 論文の内容や, 投稿状況によっては決定 に時間がかかる場合がある，現状では，多様な専門性 を持つ編集委員を多数確保することにより対処してい る。(3)の查読者割当も, 打診して断られたり, 返事 がしばらく来ないことなどがあると, 日数を要してし まう要因となる。(4)，(5) に関しては，査読は１ヶ月 (再査読は 10 日)，原稿の修正は 3 ケ月となっている が，どちらも期限を過ぎるケースがある．査読の督促 などは適宜行っているが, 査読はボランティアであ り, また査読者の都合もあるため督促が難しい状況も ある。最後に(6)に関して, 本学会では査読者 2 名 (ショートノートは 1 名)により査読が行われ, その結 果の多数決で最終判定を下すことになっている. 判定 結果が採録，不採録などに割れた場合，新たに 3 人目 を立てる必要があり, 查読者依頼, 查読にさらに日数 を要することになる。

特集論文が一般投稿よりも迅速に処理可能な理由 は, 主に二点ある。一つは, 掲載号を含むスケジュー ルが決まっているため, 論文を受け付けるゲストエ ディタ, 查読者, 投稿者の三者ともスケジュールを想 定して対応ができるためである。二点目は，投稿論文 の分野が限定されるため, 査読者をあらかじめ確保し やすいためである。従って，特集論文の持つこのよう な性質を一般投稿にも生かすことができれば，論文審 查プロセスの迅速化の余地はあると考えられ，今後の 検討課題である.

\section{4. さいごに}

本稿では, 学会設立 20 周年を記念して, 近年 $(2003$ ～2008）の学会の歩みを, 論文投稿の観点から振り 返った。また，昨年より運用を開始して 1 年が経過し たばかりの電子論文投稿審査システムについても現状 を述べた。関西から関東への編集委員会の移行，念願 であった論文投稿審査システムの電子化を果たすな ど，大きな動きのあった 10 年間と言えるが，次の 10 年間は何が起こるであろうか. 会誌は学会員にとって 有益なものでなくてはならないとともに, 外へ向けて の学会の顔とも言える。よりクオリティの高い会誌と なるよう, 今後も編集委員一同, 検討・改善を進めて いきたい。 


\section{謝辞}

本稿の執筆にあたって, 日本知能情報ファジィ学会 文献データベース委員会から文献データをご提供頂き ました。東京工業大学の片上大輔氏，ヤフー株式会社 の奥岡晋大氏からは，会誌記事・論文のキーワード分 析結果をご提供頂きました。この場を借りて謝意を表 します。
参 考 文 献

[1] 片上, データと可視化で探るSOFTの 20 年と未来, 知 能と情報, Vol.21, No. 6，2009.

[2] 和田, J-STAGEによる学協会の電子ジャーナル発行, 知能と情報, Vol.19, No. 6, pp.663-669, 2007. 